\title{
The Vices Of Social Media ON Students Success At The Adamawa State Polytechnic, YOLA- NigERIA
}

\author{
${ }^{1}$ Oye, N. D. and ${ }^{2}$ Ibrahim, Inuwa \\ ${ }^{1}$ Department of Computer Science MAUTECH- Yola Nigeria \\ ${ }^{2}$ Information Technology Department, MAUTECH, Yola - Nigeria.
}

\begin{abstract}
Social media and social networking web sites have continued to gain supremacy in determining the student's success in education. It captures the attention of students and their tutors over the years. A social media network is only an electronic links amongst its users which turned out to be a habit for students, youngsters,

and even the grown person. The influence of social media on students is alarming and doing more harm than good. The aim of the paper is to analyze the vices of social media on the academic success of students of Adamawa State Polytechnic, Yola. The survey method of research was adopted to achieve the objectives of the study. Some research questions were presented to the respondents where the results revealed that so many (96 percent of them) usually spent much time on the social networking sites than to their academics. As such, the academic success of the students suffers setbacks which lead to poor performance in the student's academics. It is therefore recommended that the networking sites should be built in such a way to support student's educational activities in a positive way, as this will help in attracting the students to get acquitted in their quest for good academic success.
\end{abstract}

\section{KEYWORDS:}

Chatting; Mobile Social Media; Social Media; Social Networking; Networking Site

\section{BACKgROUND OF THE STUDY}

It is becoming clear that the Social Networking sites such as Youtube, Twitter, Instagram, Whatsup and Facebook have become widespread amongst the students of the tertiary institution across the globe; it is so because of the charming of their features. Facebook is the most widely held social networking website amid the others. A social media network is only an electronic links amongst its users which turned out to be an habit for students, youngsters, and even the grown person. The influence of social media on students is alarming. Social media is uses mobile and web based technology to make vastly collaborating platforms in which people in a community share, co-create, discuss and modifies user's generated content (Kietzmannn, 2012).

The Internet is a very huge network; it can be regarded as the network of all networks. Networking is a set-up that links lots of computers together worldwide, creating a network that computers can communicate with each other. Andrew (2005) opined that the internet is a global highway for information decimation; it is the international collection of computer networks. The internet has a countless benefit on the life of student. It helps in every aspect $\mathrm{s}$ of his/her life. Generally, students are supposed to give much attention to their education than the social media. A number of studies were conducted on the social media its roles on student's performance most 
of the results obtained showed student are so much inclined with social media and its sites which in turn negatively affects their education.

In the present day youngster shows very much interest for using social networks but regrettably the social networking sites distress education severely. It has become a habit to students in schools to use the internet at all-time due to its eye catching features. Tariq et al. (2012) claimed that students cannot succeed because they have no wisdom of the forthcoming future and rivalries in their professions. The social network usages have taken the attention of students and raise the number of its users. Anjugu (2013) revealed that since the emergence of social media and its sites (in the 1990s), it is alleged that the academic success of students has faced with laxity and trials. There is unconventionality, interruption and divided attention amid social networking happenings and their academic effort.

Consequently, the question here is how do social media affect the academic success of students of the Adamawa State Polytechnic, Yola? What social networking sites do the students of Adamawa State Polytechnic, Yola had access to? How often do the students of Adamawa State Polytechnic, Yola go online? What is the number of hours spent by students on social networking? What is the extent at which the social media affects the student's success at the Adamawa State Polytechnic, Yola? The aim of the paper is to analyze the vices of social media on the academic success of students of Adamawa State Polytechnic, Yola. While the paper's objectives are to:

- Determine the extent at which the social media affects the student's success at the Adamawa State Polytechnic, Yola.

- Find out how often the students of Adamawa State Polytechnic Yola go online.

- Know the length of time spend by students on the internet/online daily.

- Know how the use of social media has affects the academic success of students in school.

\section{REVIEW Of RELATEd STUdies}

From when internet was invented different scholars have their views and assertions as to what constitutes an internet. The internet is a medium of mass media that is very collaborating and it spans across the globe as a network for all networks (Pluclaskas, 1994). Hafner and Lyon (1996) in their study reported that the internet was mainly developed to protect the national security against attack. According to Anjugu (2013) there are two incompatible forms of the internet origin opined by some schools of thought, the leading school of thought opined that, the internet was invented as a result of the cold war while Baron (2012) opined that the internet is a countrywide network that is capable of accommodating an active information sharing by means of a good computer network. Anjugu (2013) believed that the internet is a massive network of networks, a networking infrastructure that is capable of linking millions of computers systems universally to form a network.

Internet was used by a projected number of 50 million people globally. Okoye, (2000) revealed that Finnegan jr and Viswanath recognized three foremost purposes of mass media in the internet. The mass media impacts information opening due to factors such as the degree at which the content is attractive and tempting, the degree at which information networks are easy to get to and needed, the volume of social battle and range found in interaction. In their quest for the impact of social networking sites in the changing mind-set of the amid the youth of Bahawalpur City, In a study conducted by Shabir et al., it was revealed that lager percentage of the respondents were in agreement that the social media has a lot of influences, most especially the Facebook which is most social media preferred by respondent followed by Skype etc. the way social media used has 
affected relations from amongst different countries, it affects social standards and education of youths negatively (Shabir et al., 2014).

The advent of social network platforms may also be impacting the way in which learners engage with technology in general. For a number of years, Prensky (2001) contrast stuck between digital communities and digital settlers has been measured a comparatively precise typical of the ease with which people of a certain age rate, in precise, those born before and after 1980, use technology. Social networking and their educational uses are of attention to numerous scholars. According to Livingstone and Brake (2010) the social networking sites, like much else on the internet in lieu of a moving target for scholars and policy makers'. Recent trends indicate that 47 percent of American adults use social network. A national survey in 2009 found that 37 percent of online teenagers use social networking site which increased to 55 percent three years later (Len, Purcell, Smith and Zickuhr, 2010). Andreas and Michael (2000) are of the opinion that social media is a group of internet based application that builds on the ideological foundation and allows the creation and exchange of users - generated content. Social media has become one of the major channels of chatting through so many platforms. The internet usage consequence of social media according to Nielson (2012) is that, internet users continue to spend more time on the social media than any site. The total time spent on social media across mobile devices increased by 37 percent, 121 billion minutes in July 2012 compared to 88 billion minutes in July 2011.

According to Sofela (2012) the popularity of social media has grown expediently. The social networking site allows for social interaction among students. The study examined the positive effect of such site on youths. It is said gone are those days when events happen and it stays a while before people begin to hear about it. But now, through social media, events and news are now known within splits second after they are shared. It offers youths a channel for entertainment, communication, and meeting friends and those you've not seen for a long time. The study also analyzed the negative consequences of such site, Srivastava, (2012) on the other hand analyzed the positive and the negative sides of the social media. Despite the positive gain, it comes with the negative impact of it. It was before now used by students for research but most students abandoned their home work to chat with friends. However, the study reviewed and the present study emphasized on the impact of social media on students, stressing on the positive impact in the student's academic performance as well as the negative influence.

The study emphasized the need for students to create a balance between social media and their academics to prevent setbacks. But the reviewed study failed to throw more light on the negative influence of social media on the academic performance of students. Social media creates space for learners which James (2012) suggest empathy space and spreading of expertise and relatedness for learning. It was reported that the number of users with access to the internet was growing at the rate of 10 percent per month. Forecast were that by the turn of the century, there may be one million networks, hundred million computers and one billion users of the internet (Smith and Gibbs 1994). The study of Seyi (2012) stressed on the negative effect of giving too much time and undue attention to online socialization to the detriment of academics. According to the researcher, the 21 st century brought with it the advent of the new media with its fast tracking means of sending and receiving information via internet in our contemporary society. There is evidence of contradiction to this; 69 percent of social media using teens and 85 percent adults said people are mostly kind to one another. The national school board association reports that almost 60 percent of the students who use social network talk about educational topics online and more than 50 percent talk about school work. Yet the vast majority of school district has stringent rules against nearly all forms of social media during school hours. 


\section{Data Presentation And Analysis}

The researchers have collected data by means of questionnaire which was administered to the respondents. 150 questionnaires were distributed to the respondents and only 130 (86.7 percent) of the questionnaires distributed were returned to the researchers for analysis. The study answered the following research questions:

Question 1: What Social Networking Sites do the Students of Adamawa State Polytechnic Yola have access to?

Question a; which of the following do you own?

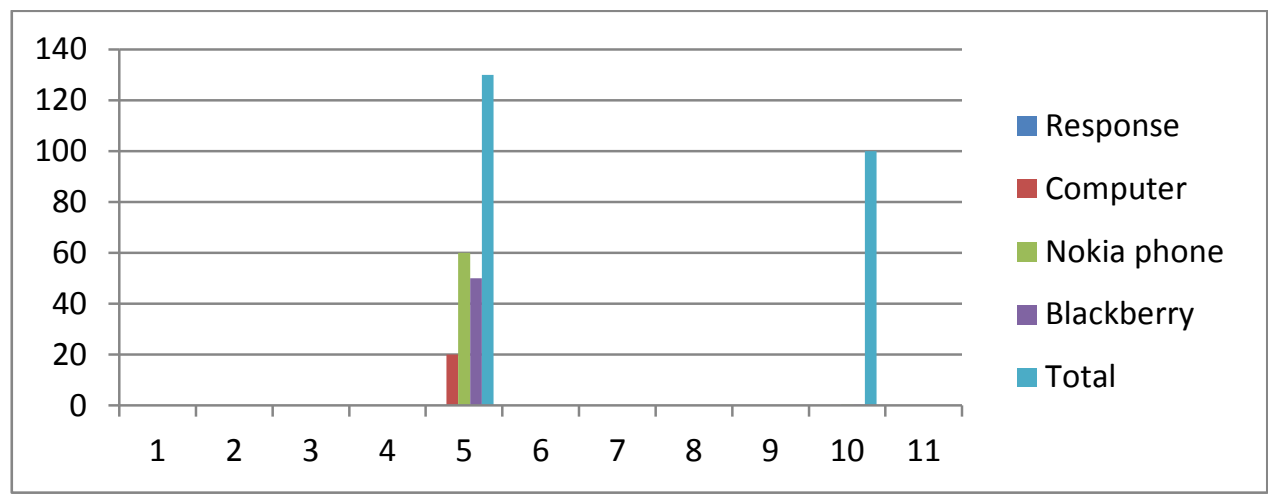

Figure 1: The Devices Possessed by Respondents

15.4 percent of the respondent in Figure 1 had a computer system while 46.1 percent of the respondent had a Phone, and 38.5 percent were in possession of a Blackberry.

Question b; are you have access to internet?

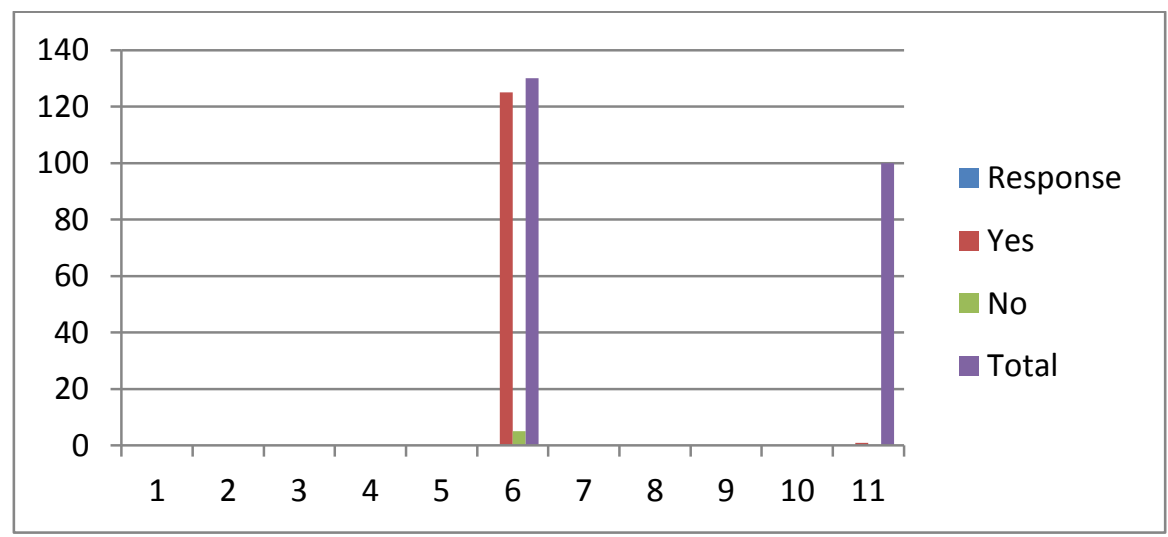

Figure 2: Access to network by Respondents

Looking at Figure 2 it is clear that 96.2 percent can access the internet while 3.8 percent cannot have an access to internet.

Question c; what is your stand on awareness to social network and its sites? 
International Journal of Computer Science \& Information Technology (IJCSIT) Vol 8, No 4, August 2016

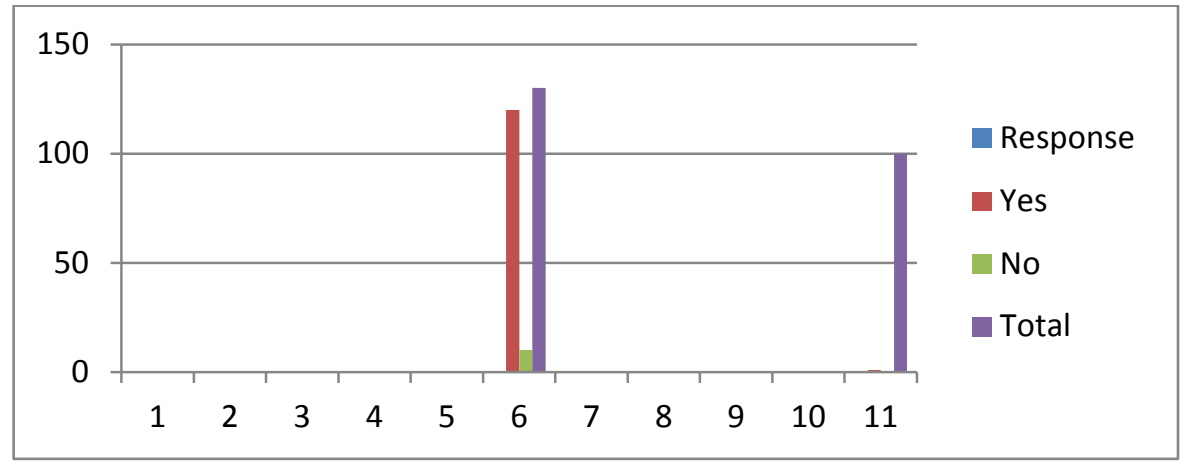

Figure 3: Awareness on social networking sites by Respondents

In Figure 3 there is a 92.3 percent of the respondents have an awareness on the social network and its sites while only 7.7 percent of the respondents reported that they have no awareness to social networking sites.

Question d; which of the social networking site do you know?

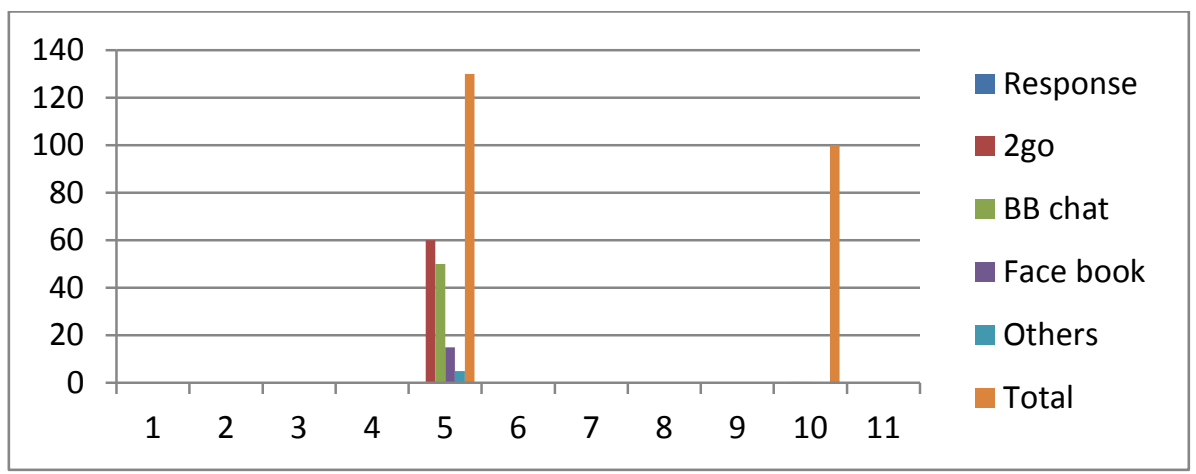

Figure 4: Types of social networking sites known to Respondents

In Figure 4 we see that 46.2 percent of respondents were conscious of 2 go site, 38.5 percent knows of the BB chat site, 11.5 percent were conversant with FACEBOOK and 3.8 percent were conversant with other sites.

Question e; which of the social networking sites do you like most?

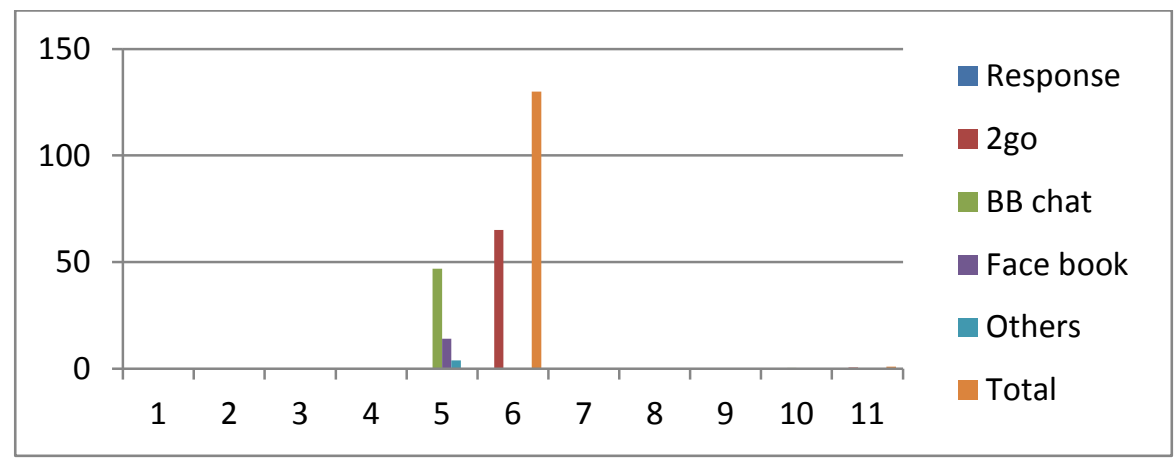

Figure 5: Respondents social networking sites preferences 
In the Figure 5 we have 50 percent of the responds desired 2go, 36.2 percent desired BB chat, 10.8 percent desired Facebook while 3.0 preferred to use others.

Question 2: how often do the students of Adamawa State Polytechnic Yola go online?

Question a; where do you browse?

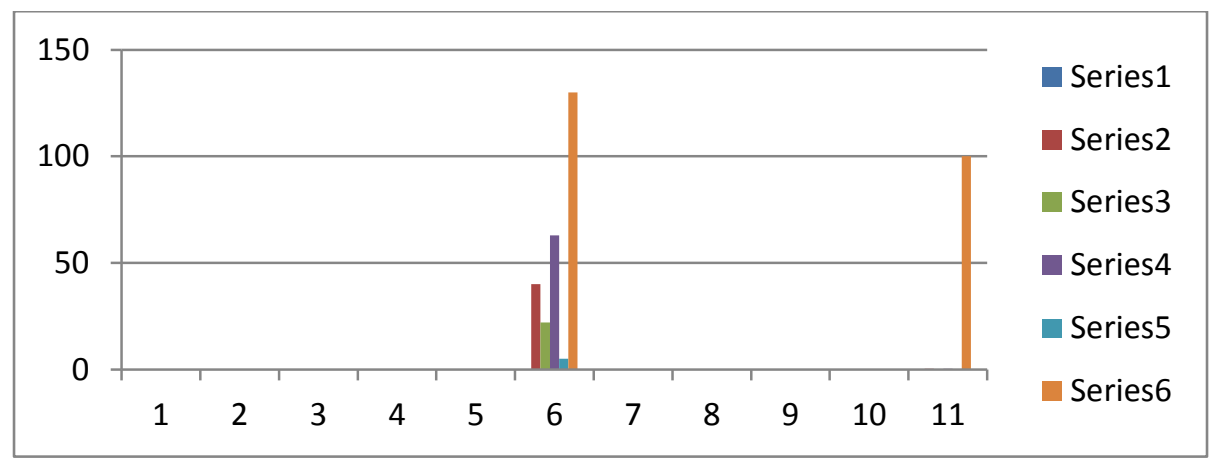

Figure 6: Preferred browsing locations of respondent

In Figure 6 it is clear that 30.8 percent of the respondent preferred to browse home-based, 16.9 percent wished to use the cafés, 48.5 percent in schools, and finally 3.8 percent of the respondent preferred others.

Question b; How frequently do you go online?

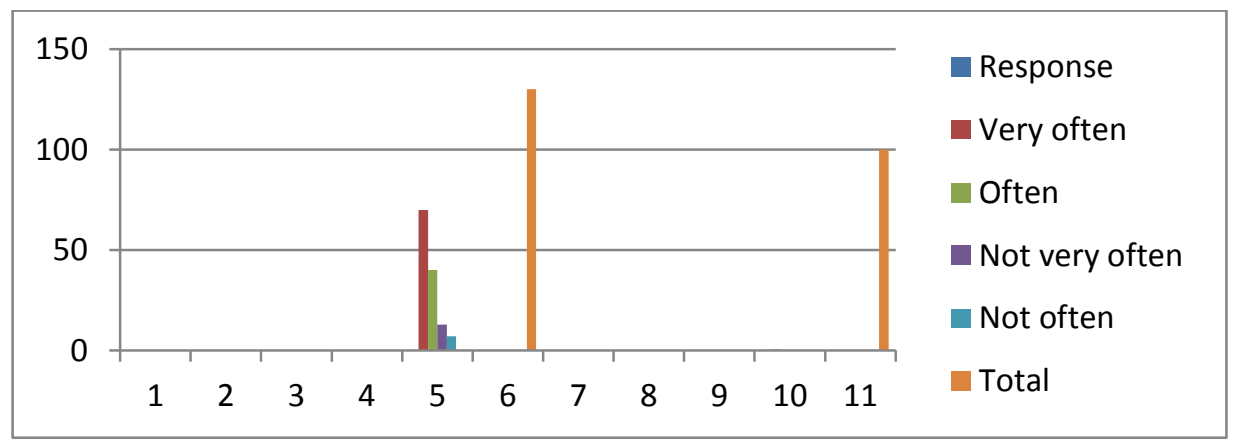

Figure 7: Frequent Use of the Internet by Respondent

Figure 7 showed that 53.8 percent uses the internet so frequent for chatting, 30.8 percent uses internet for chatting but not much, 10 percent uses the internet not so frequently to chat, and 5.4 percent of the respondents are not using internet to chat regularly.

Question 3: what is the number of hours spent by students on social networking?

Question a; how many hours do you normally spent while online? 
International Journal of Computer Science \& Information Technology (IJCSIT) Vol 8, No 4, August 2016

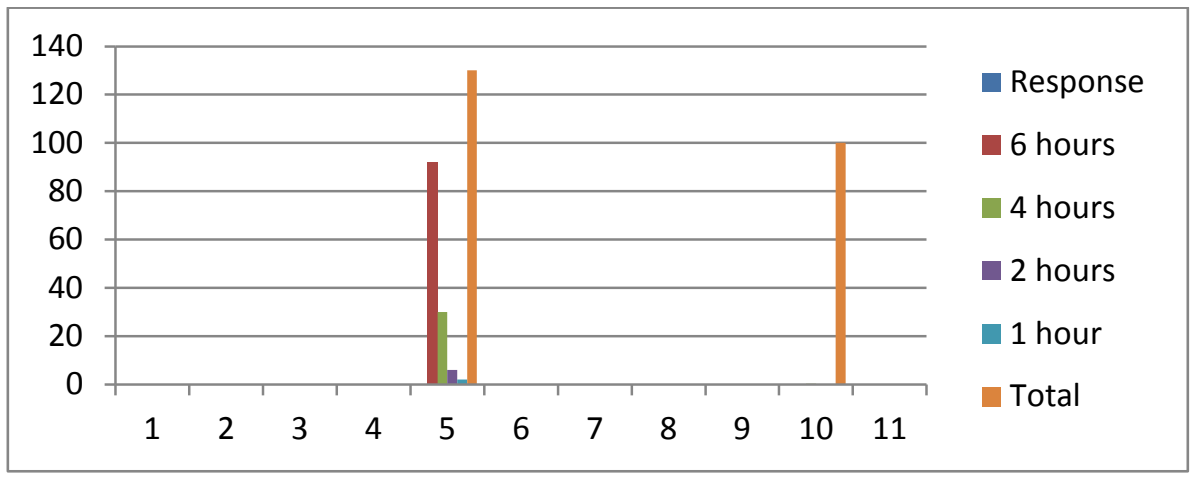

Figure 8: Time spent by student while online

According to Figure 8, 70.8 percent of the respondents usually stay online for up to 6 hours daily, 23.1 percent uses 4 hours, 4.6 percent use 2 hours and finally 1.5 percent use only an hour while online.

Question 4: what is the extent at which the social media affects the student's success at the Adamawa State Polytechnic, Yola?

Question a; what kinds of web pages do you normally surf while you are online?

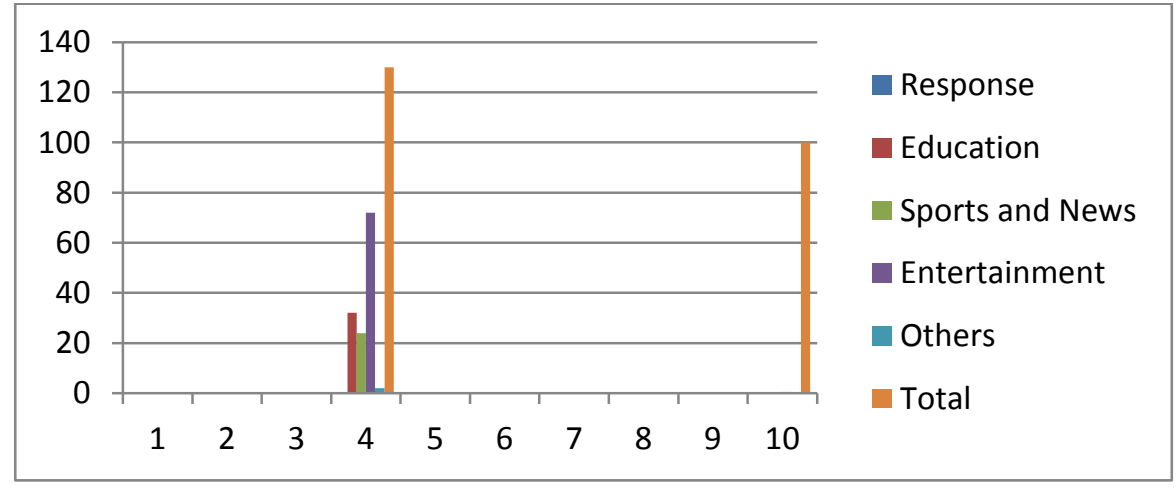

Figure 9: Respondent browsing category

The responses in Figure 932 revealed that 24.6 percent surf the internet for educational materials, 18.5 percent news/ sporting surfing, 55.4 percent entertainment and only 1.5 percent others.

Question b; what browsing activities do you like most?

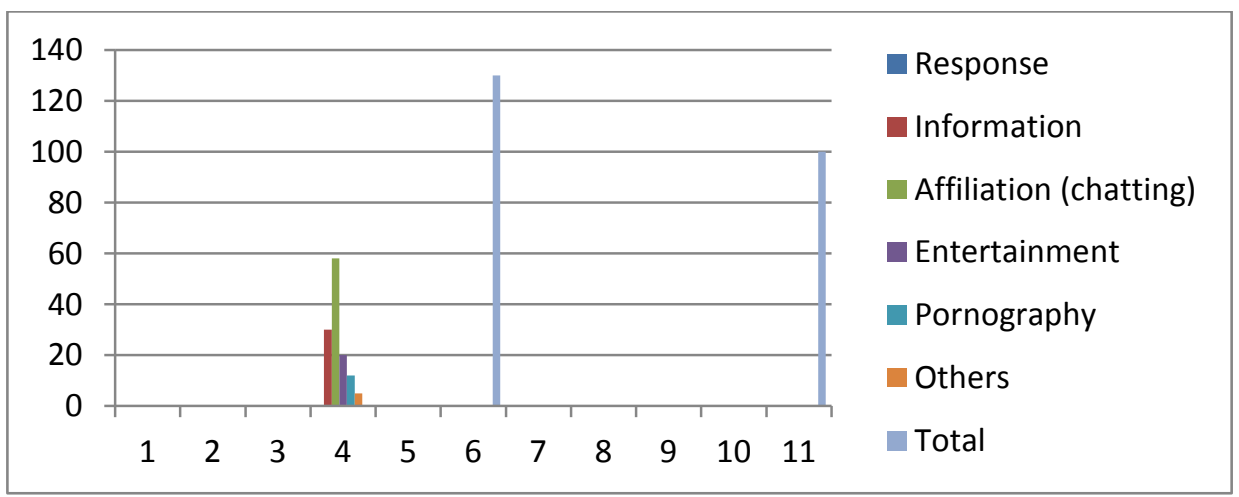

Figure 10: Respondent browsing best options. 
In Figure 10 we have 23.1 percent of the respondents prefer use the surf the internet for information gathering, 44.6 percent use it to surf for affiliation (chatting), 15.4 percent for entertainment, 9.2 percent for pornography and 3.8 percent prefer to engage in other things.

Question c; do you think that the social media and its sites have effects on the students' academic success?

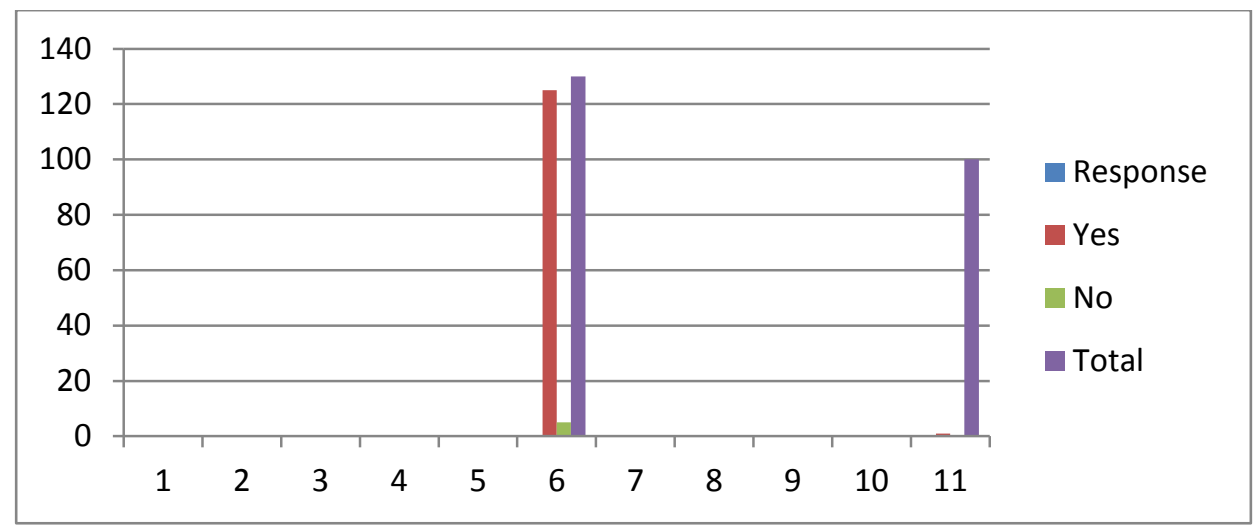

Figure 11: Views of the respondent on Social Media effects on student's success

In Figure 11 we have 96.2 percent of respondents who believed that Social Media have effects on student's success, while only 3.8 percent viewed otherwise.

Question d; how do you think the social media affects student's overall success in school?

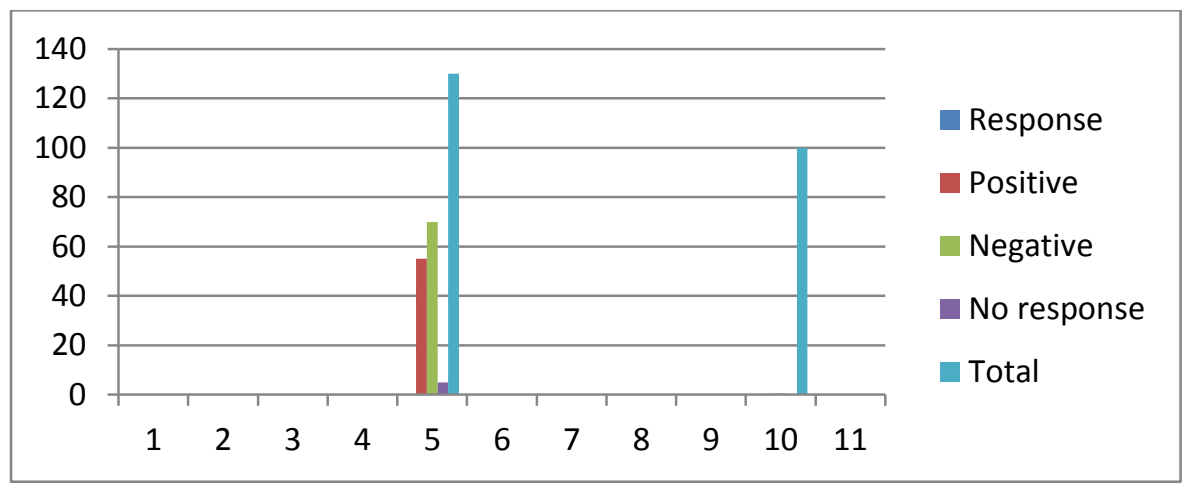

Figure 12: The social media effects on student success.

In Figure 12, 42.4 percent of the respondents alleged that the social media has positive effects on students success, 53.8 percent says it has negative effects and 3.8 percent of the responded shunned at this question.

\section{DiSCUSSION AND FINDINGS}

Question 1: This question was on the type of social networking sites accessed by students?

The researchers asked this question just to know social networking sites accessed by students. The researchers have set five questions $(\mathrm{a}-\mathrm{e})$ under question one and obtained answers which is presented in Figure 1 up to Figure 5. One can see in Figure 1 which shows that, out of the whole respondents (100 percent of them) have either a computer; phones (Nokia/BB). In the same vein 96.1 percent of the respondents can have access to the online activities, only 3.8 percent reported 
not have access to the online activities (see Figure 2). In Figure 3 it is clear that 92.3 percent of the respondents have awareness on the social network and its sites while only 7.7 percent of the respondents reported that they have no awareness to social networking sites. In Figure 4 we see that 46.2 percent of respondents were conscious of $2 \mathrm{go}$ site, 38.5 percent knows of the BB chat site, 11.5 percent were conversant with FACEBOOK and 3.8 percent were conversant with other sites. In Figure 5 the researchers collected 50 percent of the respondents that uses 2 go platform, 36.2 percent uses the BB platform, 10.8 percent uses the Facebook and only 3.0 percent uses otherwise. One can see clearly that from the results of the first research question, the students have a preference to use 2 go and BB platforms while chatting than other social networking platforms due to their user's friendly capabilities.

Question 2: The research question 2 asked about the student's frequent use of the Internet/online?

The researchers have asked this question just to know how frequently the students visit the internet on daily bases. The responses obtained can be seen in Figure 6 and Figure 7 which. In Figure 6 it is clear that 30.8 percent of the respondent preferred to browse home-based, 16.9 percent wished to use the cafés, 48.5 percent in schools, and finally 3.8 percent of the respondents preferred others. Figure 7 showed that 53.8 percent uses the internet so frequent for chatting, 30.8 percent uses internet for chatting but not much, 10 percent uses the internet not so frequently to chat, and 5.4 percent of the respondents are not using internet to chat regularly. The result obtained here revealed that almost all the respondents prefer to surf in the school than in other places as can be seen in Figure 6. The research also revealed that the students usually browse the internet so frequent to chat as can be seen in Figure 7.

Question 3: tried to get the answers as to the number of hours Students use to spend while using the internet daily?

The researchers have asked this question just to know the extent of time spend by the students while using the internet/online. It was discovered that 70.8 percent of the respondents usually stay online for up to 6 hours on daily bases, 23.1 percent of then uses 4 hours, 4.6 percent use 2 hours and finally, 1.5 percent use only an hour while online. The answers to this question revealed that students give much of their time to internet activities while in school.

Question 4: How do the social networking sites affects the student academic success at the Adamawa State Polytechnic?

The intention of the question 4 is to determine influence of social networking site on the student success. It was discovered by 32 respondents (i.e 24.6 percent) surf the internet for educational purposes, 24 responses (18.5 percent) surf the internet for reading new and sporting purposes and 72 responses (making a 55.4 percent) revealed that they surf the internet for purposes of entertainment, lastly, only 2 responses (1.5 percent) was obtained that do others activities while online as can be seen in Figure 9. 23.1 percent of the respondents revealed that they are satisfied by the gathered data while 44.6 percent of them choses chatting instead, $15.4 \%$ percent choses entertainment, 9.2 percent liked pornography, and lastly 3.8 percent of the respondent desired to go with others as can be seen in Figure 10. The Figure 11 revealed that 96.2 percent of the student's success in school can be influenced by the social media and only 3.8 percent of the respondents differed to that. $50 \%$ of the responses we obtained (see Figure 12) revealed that the social media have a negative impact on the student's success, 45.5 believed that the social media has a positive impact on their study life, only 3.8\% refused to comment on this question. According to this study, social networking sites has great positive influence when it comes to student's performance and success in school, it also influenced them negatively as a result of the kind of bad activities they normally carried out while surfing the net. 


\section{CONCLUSION}

The results obtained in this study revealed that students of Adamawa State Polytechnic Yola are very conscious of the networking sites; they know how to gain access to the sites at regular intervals. The results of the analysis also revealed that a greater number of sites affect students in a negative ways; they gave much attention things like games and chats platforms rather than educational sites.

It is therefore, recommended that the networking sites should be built in such a way to support student's educational activities, as this will help in attracting the students to get acquitted in their quest for good academic success.

\section{REFERENCES}

[1] Andreas, Y. and Micheal, K. (2000). Writing for mass media society. Nsukka: Price Publishers.

[2] Andrew, I. (2005). Reading in Computer Science and Nigeria satellite. Makurdi: Benue State University.

[3] Anjugu, J. N. (2013). Impact of Social Media on Students Academic Performance (A Study of Students of University of Abuja). Department of Mass Communication Management and Social Sciences, Caritas University Amorji - Nike, Enugu, Nigeria.

[4] Baron, J. (2012). Communication works (7th edition). New York: McGraw Hill.

[5] Hafner, F. and lyon, A. (1996). Public Opinion. New York: Macmillan Free Press.

[6] James, F. (2012). Research methodology and statistics: (standard edition) Port Harcourt: Nuel centi publishers.

[7] Kaplan, C. (2002). Microcomputer studies for beginners: (2nd edition). Onitsha: Spiritan Publication.

[8] Kaplan, E. and Heanlein, L. (2010). Media writing and reporting: (2nd edition). Enugu: Cecta.

[9] Kietzmann, J. (2012). Computer Science research: issues and methodologies. Nsukka: AP Express Publishers.

[10] Nielson, N. (2012). Introduction to Computer Science. Enugu: New Generation Books.

[11] Okoye, L. (2000). Magazine and newspaper management and production. An Introductory text. Owerri: Top Shelve Publisher.

[12] Piluclaskas, G. (1994). Public opinion. New York: Mac Millian free press.

[13] Prensky, N. (2001). Readings in Computer Science; Global Perspective of Communication Issues. Enugu: Rhyce Kerex Publishers.

[14] Seyi, O. (2012). Introduction to Computer Science: media literacy and Culture: (3rd edition). New York: McGraw hill companies.

[15] Shabir, G., Yousef, M., Ghulam, S. and Syed M. (2014). The Impact of Social Media on Youth: A Case Study of Bahawalpur City. Asian Journal of Social Sciences \& Humanities, 3(4).

[16] Smith, L. and Gibbs, S. (1994, 1998). The media: An introduction: (3rd edition). England: Pearson Education Limited.

[17] Srivastava, P. (2012). Social Networking and its Impact on Education-System in Contemporary Era. International Journal of Information Technology Infrastructure 1, 2, 11-18.

[18] Stone, G. and Brake, G. (2010). Public Opinion. New York: Macmillan Free Press.

[19] Tariq, W., Mehboob, M., Asfandyar M. K. and Ullah, F. (2012). The Impact of Social Media and Social Networks on Education and Students of Pakistan. International Journal of Computer Science Issues, 9(4), 3.

[20] Thompson, A. (2013). Media and society: critical perspectives: (2nd edition). England. 